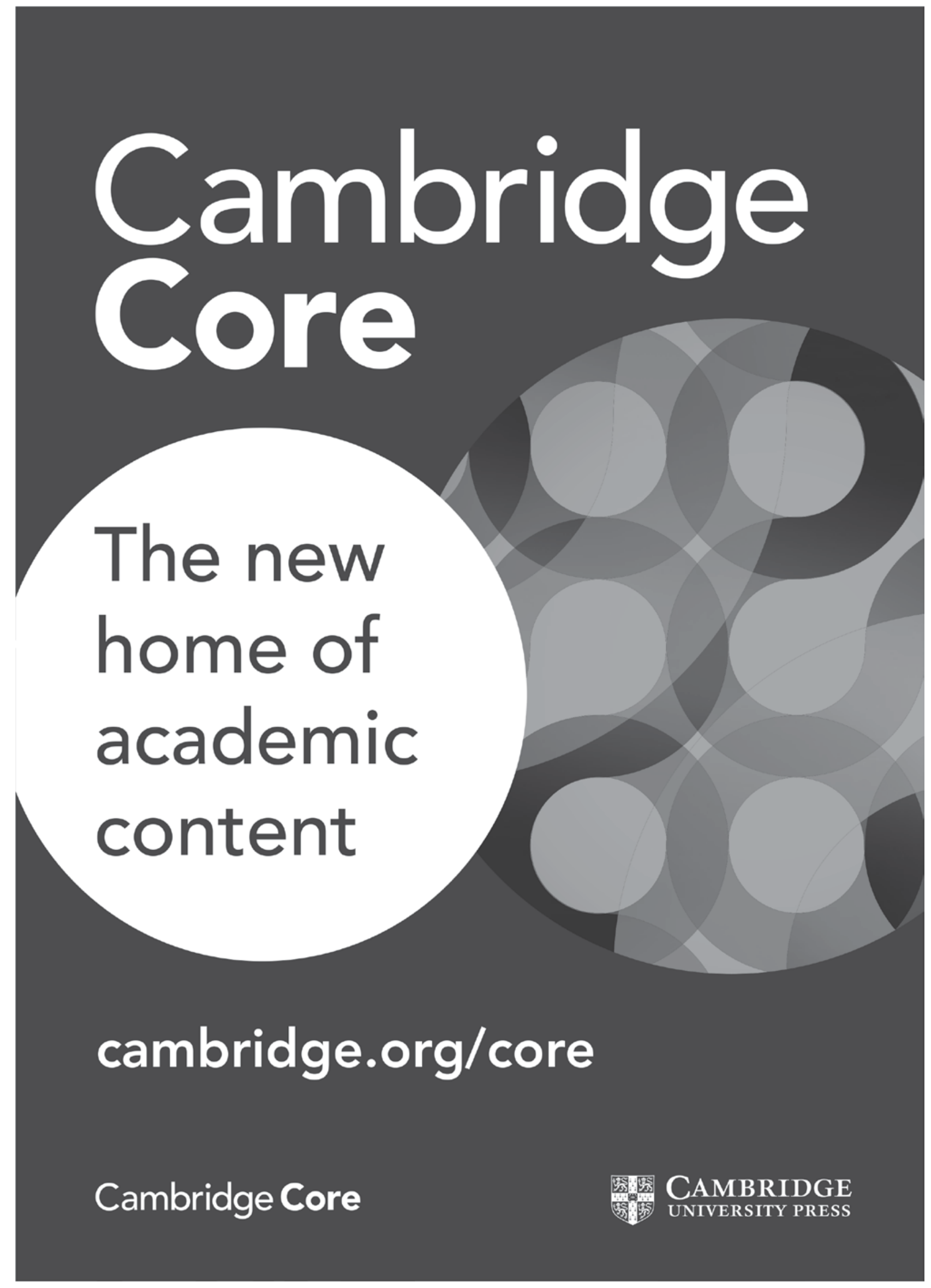




\section{GUIDELINES FOR AUTHORS}

Contributions to Children Australia from those interested in the wellbeing of children, young people and their families are encouraged. The preferred length of paper submitted is 3500-4000 words. Longer papers on topics of particular significance may be accepted in consultation with the editors.

Manuscripts may be accepted for publication, returned for revision or rejected. However, every effort will be made to help authors bring their manuscript up to the required standard for publication. Minor amendments may be made by editorial staff following review to ensure that reasonable standards of content, presentation and readability are maintained. The editors' decision is final.

In addition to the above, Children Australia welcomes brief reports (500-1500 words) on program development, policy development or research. Acceptance for publication will be on the basis of review by the editorial team.

COPYRIGHT: It is a condition of publication that copyright is assigned by the author(s) to the publisher. Copyright assignment forms will be sent to authors on receipt of their papers.

\section{GENERAL STYLE GUIDELINES}

1. Contributions should follow the format and style described in the Publication Manual of the American Psychological Association (6th ed). Spelling and punctuation should conform to The Macquarie Dictionary (4th ed). For matters of style not covered in these two publications, the Style Manual for authors, editors and printers (6th ed) should be consulted.

2. Uncommon abbreviations and acronyms should be explained. Do not use underlining except to indicate italics. Full stops should not be used in abbreviations or acronyms (e.g., NSW).

3. Use single quotation marks to introduce a word or phrase used as an ironic comment, as slang, or which has been coined. Use quotation marks the first time the word or phrase is used; do not use them again. Do not use quotation marks to introduce a technical or key term. Instead, italicise the term.

4. Do not use any footnotes. Endnotes should be kept to a minimum and listed at the end of the text under the centred heading 'Endnotes'. Acknowledgments should be placed at the end of the article with a separate heading.

5. A list of figure captions should follow the tables in the manuscript.
6. References should follow the format and style described in the Publication Manual of the American Psychological Association (6th ed).

Examples of citations are:

The theory was first propounded in 1970 (Larsen, 1971). Larsen (1971) was the first to propound the theory.

Examples of references are:

Larson, P.J., \& Maag, J.W. (1998). Applying functional assessment in general education classrooms. Issues and recommendations. Remedial and Special Education, 19, 338-349.

Sheridan, S.M. (1998). Social skills training for ADHD children. In S. Goldstein \& M. Goldstein, (Eds.), Managing attention deficit hyperactivity disorder in children (pp. 592-612). New York: John Wiley.

\section{AUTHOR MANUSCRIPT CHECKLIST}

Please ensure the following are included in your submission:

- first name and surname of all authors

- affiliations (institution and country) of all authors

- name and full postal and e-mail address of the corresponding author

- running head of maximum 50 characters including spaces

- up to 6 keywords

- abstract of no more than 250 words in length

- the approximate positions of all tables and figures mentioned in the text indicated by the words 'Insert Table/Figure $\mathrm{X}$ about here'

- APA style for citations, references, numbers, capitalisation, table and figure captions, and statistical symbols

- all figures supplied separate to text in PDF format, NOT in colour, and clearly readable.

Any enquiries should be addressed to:

Dr Jennifer Lehmann,

Editor, Children Australia,

School of Social Work \& Social Policy, Bendigo Campus, La Trobe University.

Email: J.Lehmann@latrobe.edu.au

Dr Rachael Sanders

Email: rachael_s50@hotmail.com

Manuscripts, book reviews and editorial communications may be submitted through ScholarOne: https://mc. manuscriptcentral.com/cha 


\section{Children Australia}

\section{EDITORIAL}

Innovation: Are we really creating something new?

Jennifer Lehmann

\section{ARTICLES}

Assessing allegations of child sex abuse in custody disputes

Emily Schindeler

Young person's well-being: Exploring material, subjective and relational factors

Margot Rawsthorne, Grace Kinsela, Karen Paxton and Georgina Luscombe

Development of facial emotion recognition and empathy test (FERET)

for primary school children

Kerem Coskun

\section{REVIEW ARTICLES}

The tripartite tragedy: Alcohol and other drugs, intimate partner violence and child abuse Mohajer Abbass Hameed

Childhood abuse or trauma: A racial perspective

Janine Oldfield and Theresa Jackson

\section{BOOK REVIEWS}

Protecting children: A social model

Frank Ainsworth

The hope circuit. A psychologist's journey from helplessness to optimism

Frank Ainsworth 